\title{
Insulin Secretion by Fetal Human Pancreas in Organ Culture
}

\author{
L.Hoffman ${ }^{1}$, T.E.Mandel ${ }^{2}$, W. M.Carter ${ }^{2}$, M.Koulmanda ${ }^{2}$ and F. I.R. Martin ${ }^{1}$ \\ ${ }^{1}$ Department of Diabetes and Endocrinology and 'the Walter and Eliza Hall Institute of Medical Research, \\ Royal Melbourne Hospital, Victoria, Australia
}

\begin{abstract}
Summary. Whole fetal human pancreases of 12-22 weeks gestation, showed histological growth and differentiation in vitro over 3 weeks. At glucose concentrations of $1-4 \mathrm{~g} / 1$, there was no difference in insulin secretion into culture medium over $1 \mathrm{~h}$. There was no stimulation of insulin release by D-glyceraldehyde, thus defective glucose-stimulated insulin release was probably not due to impairment of an early step in glycolysis. In the presence of $0.5 \mathrm{mmol} / 1$ dibutyryl cyclic AMP, insulin secretion was enhanced $(0.188 \pm 0.030$ versus $0.100 \pm$ $0.012 \mathrm{mU} \cdot \mathrm{mg}$ tissue $\left.{ }^{-1} \cdot \mathrm{h}^{1}, p<0.001\right)$ independently of glucose concentrations. It thus appears that impairment of glucose-stimulated insulin release was unlikely to be due to insufficient intracellular cyclic AMP. Insulin release increased in
\end{abstract}

response to tolbutamide and theophylline. Insulin secretion was stimulated in the presence of a fivefold increase in amino acid concentration $(0.118 \pm 0.018$ versus $0.031 \pm$ $\left.0.008 \mathrm{mU} \cdot \mathrm{mg} \mathrm{tissue}^{-1} \cdot \mathrm{h}^{-1}, p<0.001\right)$. There was a fourfold increase in basal insulin secretion from islets previously grown in high concentration of amino acids compared with standard culture medium, $(0.284 \pm 0.052$ versus $0.067 \pm 0.011 \mathrm{mU} \cdot \mathrm{mg}$ tissue $^{-1} \cdot \mathrm{h}^{-1}, p<0.001$ ), emphasizing the important role of amino acids as substrates for $B$ cell metabolism and development.

Key words: Fetal pancreas, morphology, insulin secretion, secretagogues.
Pancreatic islet transplantation has potentially wide application in the treatment of insulin-dependent diabetes mellitus. However, the limited availability of suitable donors, the poor recovery of isolated islets from adult human pancreas, and rejection of foreign tissue by the host, are problems still requiring solution [1]. Since fetal tissue has a large potential for proliferation, the fetal pancreas may provide a way of obtaining sufficient islet cells from each donor [2]. In organ culture of pancreas, selective endocrine differentiation and simultaneous degeneration of acinar cells occurs [3] and provides a potentially efficient way of harvesting islets. Evidence is also accumulating for modification of immunogenicity of pancreatic islets in organ culture [4-6].

We have described previously an organ culture technique whereby whole fetal mouse thymus [7] and pancreatic islets [8] will differentiate and proliferate in vitro for prolonged periods. Diabetes was reversed $[9,10]$ and the renal complications were prevented [11] following transplantation of the tissue. This culture method has now been extended to study the growth and differentiation of fetal human pancreas.

\section{Materials and Methods}

\section{Organ Culture Technique}

Ten human fetal pancreases of 12-22 weeks gestation were obtained from hysterotomies or prostaglandin-induced abortions; the cold ischaemia time for the specimens being up to $10 \mathrm{~h}$. The pancreas was dissected under sterile conditions in phosphate buffered saline and was cut into fragments of $0.5-1 \mathrm{~mm}^{3}$. These were placed on to strips of millipore filter $(0.45 \mu \mathrm{m}$ pore size) lying on blocks of surgical gelatin foam (Gelfoam, Upjohn, Kalamazoo, USA) in $9 \mathrm{~cm}$ Petri dishes containing $15 \mathrm{ml}$ of Dulbecco's Modified Eagle's Medium (DMEM) (Flow Laboratories, North Ryde, NSW, Australia) supplemented with $15 \%$ fetal calf serum. The tissue was maintained at the gas $/$ medium interface. The medium contained penicillin $(60 \mathrm{mg} / 100 \mathrm{ml})$ and streptomycin $(100 \mathrm{mg} / 100 \mathrm{ml})$ and glucose $(1 \mathrm{~g} / 1)$, unless otherwise indicated. Media were changed twice weekly. Each dish contained fragments equivalent to approximately one-fifth of one pancreas. The dishes were maintained at $37^{\circ} \mathrm{C}$ in a humidified incubator in $10 \%$ $\mathrm{CO}_{2}$ in air. Catalogue numbers of all reagents are available on request.

\section{Histological Preparation}

Some pancreatic fragments were placed in Bouin's fixative immediately after removal from a fetus, and further fragments from the same 


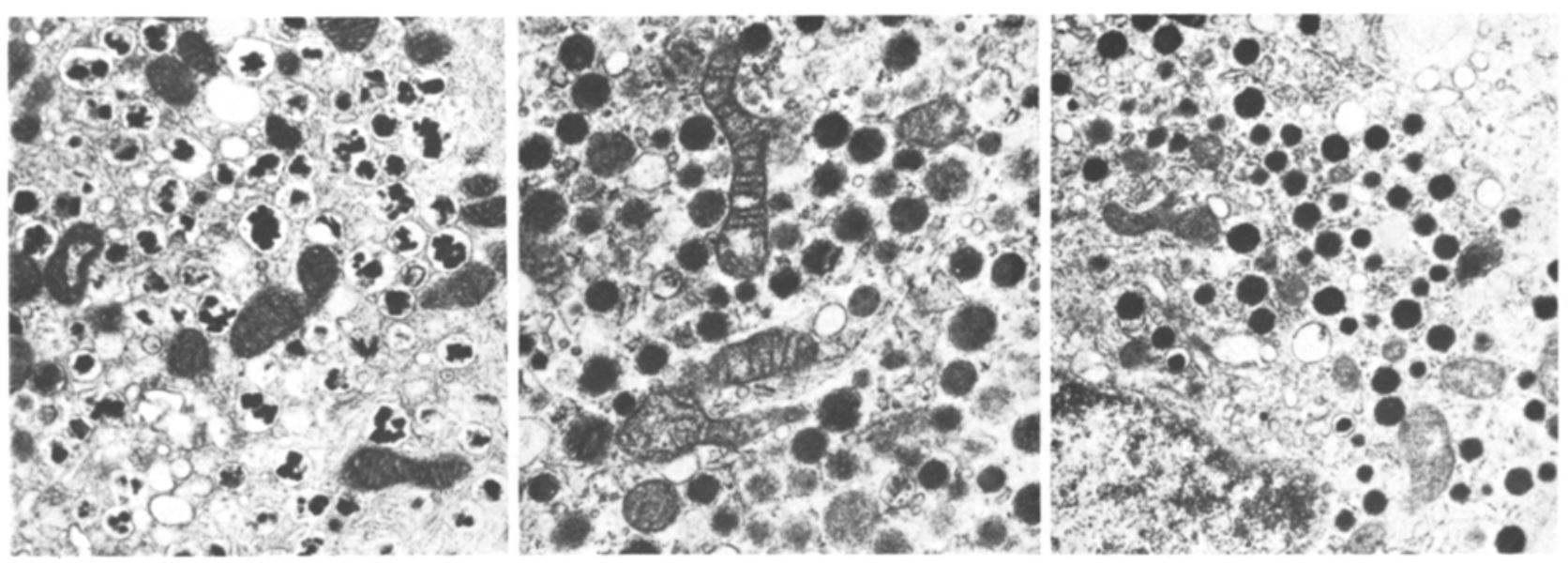

Fig. 1. Electron micrograph showing the characteristic structure of islet cell granules of B, D and A cells (left to right) from a 12 week fetal pancreas after 3 weeks in vitro $(\times 23,000)$

pancreases were fixed after 3 weeks in organ culture. The tissues were processed for light microscopy and $5 \mu \mathrm{m}$ sections were cut and stained with hematoxylin and eosin, and Gomori aldehyde fuchsin stains. For electron microscopy, tissue was fixed in dilute Karnovsky fixative (1\% glutaraldehyde and $1.2 \%$ paraformaldehyde in $80 \mathrm{mmol} / 1$ cacodylate buffer), washed overnight in cacodylate buffer and postfixed in $2 \%$ osmium tetroxide followed by $2 \%$ aqueous uranyl acetate. Following dehydration in acetone, the tissue was embedded in Spurrs' low viscosity resin. Thin sections, stained with saturated uranyl acetate in $70 \%$ ethanol followed by lead citrate, were examined in a Philips 300 electron microscope.

\section{Determination of Pancreatic Insulin Content}

Insulin was extracted from fragments of seven pancreases of 12,16 or 22 weeks gestation, by a method similar to that used by Lundgren et al. [12]. Pancreatic fragments were sonicated in $3 \mathrm{ml}$ acid ethanol $\left(15 \mathrm{ml} 12 \mathrm{~N} \mathrm{HC} 1 / 170 \%\right.$ ethanol), extracted for $24 \mathrm{~h}$ at $4{ }^{\circ} \mathrm{C}$, and stored at $-20^{\circ} \mathrm{C}$ before radioimmunoassay of insulin [13]. Insulin content was expressed as $\mathrm{mU}$ insulin/ $\mathrm{mg}$ wet weight of tissue.

\section{Determination of Insulin Secretion Under Basal and Stimulating Conditions}

Forty-eight pancreatic fragments from a fetus of 16 weeks gestation were grown for 16 days, following which insulin secretion during $1 \mathrm{~h}$ in DMEM with $1 \mathrm{~g}$ glucose/ I was measured by radioimmunoassay [13]. The lower limit of sensitivity of the insulin assay was $2.5 \mathrm{mU} / 1$, the intra-assay coefficient of variation was $3 \%$, and interassay coefficient of variation was $7 \%$. For measurement of insulin release over hourly periods, the fragments on millipore filter strips were transferred from Petri dishes into individual Falcon tubes and submerged in $1 \mathrm{ml}$ of fresh medium [14]. The fragments were divided into four equal groups and insulin release over a second hour was measured in one of the following solutions: (a) DMEM with $1 \mathrm{~g}$ glucose/1, (b) DMEM with $4 \mathrm{~g}$ glucose $/ 1$, (c) D-glyceraldehyde $5 \mathrm{mmol} / 1$ and (d) tolbutamide $100 \mu \mathrm{g} / \mathrm{ml}$ (Hoechst, Frankfurt, FRG).

The effect of dibutyryladenosine $3^{\prime}, 5^{\prime}$ cyclic monophosphate (dibutyryl cyclic AMP) (Sigma Chemicals, St. Louis, USA) on insulin secretion was studied using 40 pancreatic fragments, previously cultured for 7 days, from a fetus of 14 weeks gestation. Insulin secretion during the first hour in DMEM with $1 \mathrm{~g}$ glucose $/ 1$ was measured for each fragment. During the second hour, insulin release was measured as above in one of the following solutions (10 fragments/group): (a) DMEM with $1 \mathrm{~g}$ glucose $/$, (b) DMEM with $4 \mathrm{~g}$ glucose/1, (c) DMEM with $1 \mathrm{~g}$ glucose $/ 1$ plus $0.5 \mathrm{mmol} / \mathrm{l}$ dibutyryl cyclic AMP and (d)
DMEM with 4 g glucose/1 plus $0.5 \mathrm{mmol} / 1$ dibutyryl cyclic AMP. During the third hour, insulin secretion was measured in DMEM with $1 \mathrm{~g}$ glucose $/ 1$ plus $10 \mathrm{mmol} / \mathrm{I}$ theophylline.

The effect of a combined amino acid and glucose stimulus on insulin release was studied using 28 pancreatic fragments, previously grown under basal conditions for 21 days, from a fetus of 14 weeks gestation. Augmented concentrations of amino acids above standard DMEM were made by diluting modified essential amino acid solution $(50 \times)$ (Flow Laboratories, North Ryde, NSW, Australia) to a final X5 concentration in DMEM, and by diluting modified non-essential amino acid solution (Flow Laboratories) to a final X5 concentration in DMEM. This resulted in final concentrations of individual amino acids between three- and sixfold higher than in standard medi$\mathrm{um}$. The medium with augmented amino acids is hereafter described as ' $5 \mathrm{AA}$ ' to distinguish it from the amino acid concentration in standard DMEM ('1AA'). After incubation for $1 \mathrm{~h}$ in DMEM with $1 \mathrm{~g}$ glucose $/ 1$, four groups of fragments (seven/group) were transferred to fresh media of one of the following compositions for a second hour: (a) DMEM with standard glucose and amino acids (1 g, 1AA), (b) DMEM with high amino acids (1 g, 5AA), (c) DMEM with $4 \mathrm{~g}$ glucose $/ 1$ ( $4 \mathrm{~g}, 1 \mathrm{AA})$ and (d) DMEM with $4 \mathrm{~g}$ glucose/1 plus high amino acids ( $4 \mathrm{~g}, 5 \mathrm{AA})$. After measurement of insulin release over the $2 \mathrm{~h}$, the 28 fragments were removed from individual Falcon tubes and placed back into one of four Petri dishes, each group of seven fragments being maintained in one dish. The tissue was then grown for one further week in DMEM with one of the following compositions: (a) $1 \mathrm{~g}, 1 \mathrm{AA}$, (b) $1 \mathrm{~g}, 5 \mathrm{AA}$, (c) $4 \mathrm{~g}, 1 \mathrm{AA}$ and (d) $4 \mathrm{~g}, 5 \mathrm{AA}$. At the end of 1 week, the acute $1 \mathrm{~h}$ release of insulin in standard DMEM with $1 \mathrm{~g}$ glucose/ 1 was measured for each fragment to determine whether there was any difference in the rate of basal insulin secretion induced by the variable culture conditions. In order to measure glucose stimulated insulin release, all fragments were transferred for a second hour to Falcon tubes containing DMEM with $4 \mathrm{~g}$ glucose/ 1 . The fragments were then transferred for a third hour into DMEM with $4 \mathrm{~g}$ glucose/ 1 plus 10 $\mathrm{mmol} / 1$ theophylline. Statistical analyses were performed by Student's t-test.

\section{Results}

The light microscopic appearance of uncultured fetal pancreas of 12 weeks gestation showed that the tissue was largely composed of poorly differentiated ducts lined by a single layer of cuboidal epithelium and embedded in loose connective tissue. The ducts contained 
a few islet cells in their walls. After 3 weeks in culture, no acinar tissue was present but well developed islets containing endocrine cells were apparent. The Gomori aldehyde fuchsin stain revealed well stained $B$ cells. Electron microscopic examination confirmed the presence of well differentiated A, B and D cells containing large numbers of typical granules (Fig. 1). Insulin content of seven fetal pancreases increased with gestational age, ranging between $1.992 \mathrm{mU} / \mathrm{mg}$ tissue for a 12 weeks pancreas previously cultured for 9 days to $13.776 \mathrm{mU} / \mathrm{mg}$ tissue for uncultured 22 week pancreas.

Insulin secretion in response to glucose, D-glyceraldehyde and tolbutamide is shown in Table 1. During hour 2, basal insulin release in control tubes was consistently decreased compared with hour 1 . No increase in insulin release above control values was demonstrated in response to either glucose or D-glyceraldehyde. However, tolbutamide significantly stimulated insulin secretion $(0.265 \pm 0.035$ versus $0.110 \pm 0.010 \mathrm{mU} \cdot \mathrm{mg}$ tissue $\left.^{-1} \cdot \mathrm{h}^{-1}, p<0.01\right)$.

The results of the response of fetal pancreas to dibutyryl cyclic AMP and theophylline are shown in Figure 2. Insulin secretion was significantly enhanced by transferring pancreatic fragments from DMEM to standard medium plus $0.5 \mathrm{mmol} / 1$ dibutyryl cyclic AMP $(0.188 \pm 0.030$ versus $0.100 \pm 0.012 \mathrm{mU} \cdot \mathrm{mg}$ tis$\left.\mathrm{sue}^{-1} \cdot \mathrm{h}^{-1}, p<0.001\right)$. Similarly, insulin secretion was enhanced by transferring pancreatic fragments from DMEM to medium containing both $4 \mathrm{~g}$ glucose $/ 1$ plus $0.5 \mathrm{mmol} / 1$ dibutyryl cyclic AMP $(0.182 \pm 0.036$ versus $0.096 \pm 0.016 \mathrm{mU} \cdot \mathrm{mg}$ tissue $\left.\mathrm{e}^{-1} \cdot \mathrm{h}^{-1}, p<0.001\right)$. Insulin secretion during hour 2 in the presence of $0.5 \mathrm{mmol} / 1$ dibutyryl cyclic AMP was not different in the presence or absence of the additional hyperglycaemic stimulus. In hour 3, insulin secretion was clearly increased by theophylline in all groups.

Insulin release was significantly increased during hour 2 , in ' $1 \mathrm{~g}, 5 \mathrm{AA}$ ' medium compared with that from ' $1 \mathrm{~g}, 1 \mathrm{AA}^{\prime}$ ' medium $(0.118 \pm 0.018$ versus $0.031 \pm$ $0.008 \mathrm{mU} \cdot$ tissue $^{-1} \cdot \mathrm{h}^{-1}, p<0.001$ ) (Table 2). Similarly, insulin secretion was greater in ' $4 \mathrm{~g}, 5 \mathrm{AA}$ ' medium than in ' $4 \mathrm{~g}, 1 \mathrm{AA}$ ' medium $(0.090 \pm 0.020$ versus $0.043 \pm$ $0.005 \mathrm{mU} \cdot \mathrm{mg}$ tissue $\left.\mathrm{e}^{-1} \cdot \mathrm{h}^{-1}, p<0.001\right)$. Insulin secretion during hour 2 by pancreatic fragments in medium with high amino acid concentration was not increased by higher glucose.

After the fragments had been maintained for one further week in organ culture under varying culture conditions, insulin secretion under basal conditions was significantly enhanced in the two groups which had been maintained for the preceding week in high amino acids (Fig. 3). Basal insulin release from fragments cultured in ' $1 \mathrm{~g}, 5 \mathrm{AA}$ ' medium was $0.284 \pm 0.052 \mathrm{mU}$ - tissue $^{-1} \cdot \mathrm{h}^{-1}$ compared with $0.067 \pm 0.011 \mathrm{mU} \cdot \mathrm{mg}$ tissue $^{-1} \cdot \mathrm{h}^{-1}$ from fragments which had been grown in ' $1 \mathrm{~g}$, 1AA', $(p<0.001)$. Similarly, fragments grown in ' $4 \mathrm{~g}$, 5AA' secreted $0.206 \pm 0.028 \mathrm{mU} \cdot \mathrm{mg}$ tissue $\mathrm{e}^{-1} \cdot \mathrm{h}^{-1} \mathrm{com}-$ pared with $0.092 \pm 0.025 \mathrm{mU} \cdot \mathrm{mg}$ tissue ${ }^{-1} \cdot \mathrm{h}^{-1}$ from
Table 1. Insulin release from pancreatic fragments from a fetus of 16 weeks gestation

\begin{tabular}{|c|c|c|c|}
\hline $\begin{array}{l}\text { Group of } \\
\text { fragments }\end{array}$ & $\begin{array}{l}\text { Basal insulin } \\
\text { release in the } \\
\text { first hour } \\
\left(\mathrm{mU} \cdot \mathrm{mg}^{-1} \cdot \mathrm{h}^{-1}\right)\end{array}$ & $\begin{array}{l}\text { Stimulus } \\
\text { during the } \\
\text { second hour }\end{array}$ & $\begin{array}{l}\text { Insulin release } \\
\text { during the } \\
\text { second hour } \\
\left(\mathrm{mU} \cdot \mathrm{mg}^{-1} \cdot \mathrm{h}^{-1}\right)\end{array}$ \\
\hline A & $0.100 \pm 0.035$ & Glucose $(1 \mathrm{~g} / 1)$ & $0.060 \pm 0.015$ \\
\hline B & $0.085 \pm 0.010$ & Glucose $(4 \mathrm{~g} / \mathrm{l})$ & $0.070 \pm 0.010$ \\
\hline $\mathrm{C}$ & $0.110 \pm 0.030$ & $\begin{array}{l}\text { D-glyceral- } \\
\text { dehyde } \\
(5 \mathrm{mmol} / 1)\end{array}$ & $0.080 \pm 0.015$ \\
\hline $\mathrm{D}$ & $0.110 \pm 0.010$ & $\begin{array}{l}\text { Tolbutamide } \\
(100 \mu \mathrm{g} / \mathrm{ml})\end{array}$ & $0.265 \pm 0.035^{\mathrm{a}}$ \\
\hline
\end{tabular}

Results expressed as mean \pm SEM of 12 estimations.

a Second hour $>$ first hour $p<0.01$

Table 2. The effect of variable amino acid and glucose concentrations on insulin release from human fetal pancreas of 14 weeks gestation

\begin{tabular}{llll}
\hline $\begin{array}{l}\text { Group of } \\
\text { fragments }\end{array}$ & $\begin{array}{l}\text { Basal insulin } \\
\text { release in the } \\
\text { first hour } \\
\left(\mathrm{mU} \cdot \mathrm{mg}^{-1} \cdot \mathrm{h}^{-1}\right)\end{array}$ & $\begin{array}{l}\text { Stimulus } \\
\text { during the } \\
\text { second hour }\end{array}$ & $\begin{array}{l}\text { Insulin release } \\
\text { during the } \\
\text { second hour } \\
\left(\mathrm{mU} \cdot \mathrm{mg}^{-1} \cdot \mathrm{h}^{-1}\right)\end{array}$ \\
\hline $\mathrm{A}$ & $0.026 \pm 0.004$ & ' $1 \mathrm{~g}, 1 \mathrm{AA}$ ' & $0.031 \pm 0.008$ \\
$\mathrm{~B}$ & $0.028 \pm 0.004$ & $' 1 \mathrm{~g}, 5 \mathrm{AA}$ ' & $0.118 \pm 0.018^{\mathrm{a}}$ \\
$\mathrm{C}$ & $0.051 \pm 0.012$ & ' $4 \mathrm{~g}, 1 \mathrm{AA} '$ & $0.043 \pm 0.005$ \\
$\mathrm{D}$ & $0.037 \pm 0.006$ & $4 \mathrm{~g}, 5 \mathrm{AA}^{\mathrm{a}}$ & $0.090 \pm 0.020^{\mathrm{a}}$ \\
\hline
\end{tabular}

Results expressed as mean \pm SEM of seven estimations

${ }^{a}$ During the second hour: $\mathrm{B}>\mathrm{A}, \mathrm{D}>\mathrm{C}, p<0.001$

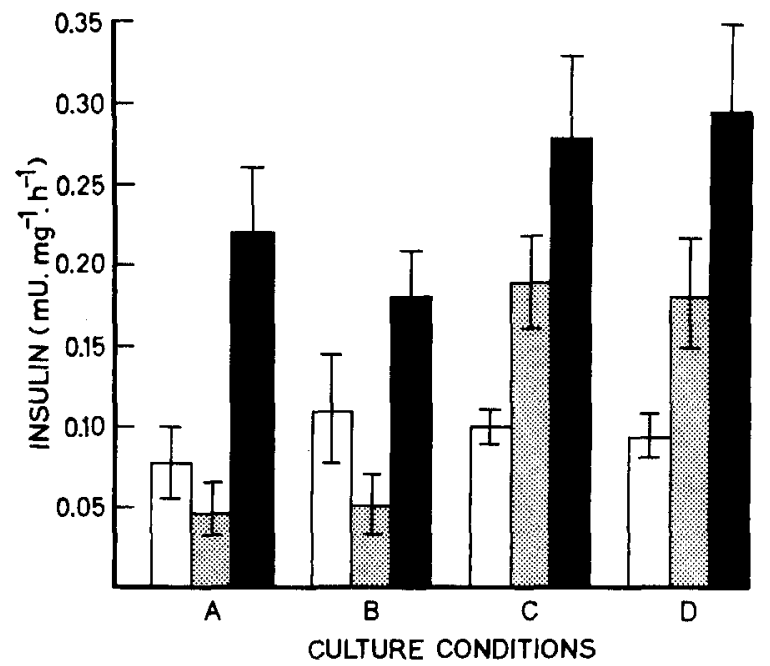

Fig. 2. The effect of dibutyryl cyclic AMP and theophylline on insulin secretion from 14 week fetal pancreas. Hour $1(\square)=1 \mathrm{~g}$ glucose $/$; hour 2 (圈): (A) 1 g glucose $/ 1$, (B) 4 g glucose $/$, (C) 1 g glucose $/ 1$ plus $0.5 \mathrm{mmol} / 1$ dibutyryl cyclic AMP or (D) $4 \mathrm{~g}$ glucose $/ 1$ plus $0.5 \mathrm{mmol} / 1$ dibutyryl cyclic AMP; hour $3(\boldsymbol{\square})=10 \mathrm{mmol} / \mathrm{l}$ theophylline. Results expressed as mean \pm SEM of 10 estimations 


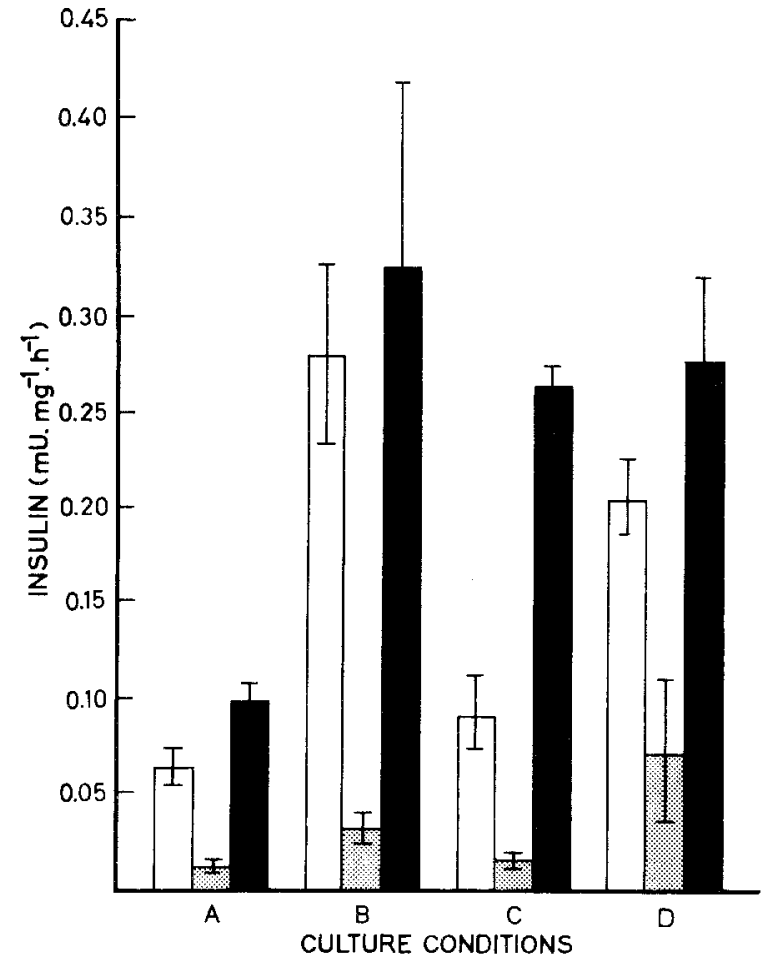

Fig. 3. The effect of previous high amino acid and/or glucose concentration on acute insulin release from 14 week fetal pancreas. Previous culture conditions: (A) ' $1 \mathrm{~g}, 1 \mathrm{AA}$ ', (B) ' $1 \mathrm{~g}, 5 \mathrm{AA}$ ', (C) ' $4 \mathrm{~g}$, 1AA' and (D) ' $4 \mathrm{~g}, 5 \mathrm{AA}$ '. Hour $1(\mathrm{D})=1 \mathrm{~g}$ glucose $/ 1$; hour 2 (圈) $=4 \mathrm{~g}$ glucose $/ 1$ and hour $3(\boldsymbol{\square})=4 \mathrm{~g}$ glucose $/ 1$ plus $10 \mathrm{mmol} / 1$ theophylline. Results expressed as mean \pm SEM of seven estimations

fragments previously cultured in ' $4 \mathrm{~g}, 1 \mathrm{AA}^{\prime}(p<0.001)$. Despite increased basal insulin secretion from fragments grown in medium with an augmented amino acid concentration, there was no response to a hyperglycaemic stimulus during the second hour of incubation. In all groups insulin release was stimulated by theophylline.

\section{Discussion}

Results of histological studies confirmed that the organ culture system used provided conditions suitable for growth and differentiation of fetal human pancreatic islets. The insulin content of fetal pancreas of 12 weeks gestation was similar to the insulin content of adult cadaver pancreas [15]. Measurement of insulin content from 22 week fetal pancreas was comparable per mg tissue to the reported insulin content of infant human pancreas [15].

The fetal human pancreas did not secrete insulin in response to glucose, a finding consistent with previous studies in vivo [16] and in vitro [17]. Recent reports have suggested that the fetal human pancreas can respond to glucose in vitro [18-20]. However the responses were minimal despite a big glucose load. It is possible that the glucose-insulin dose response curve is different in fetal and adult pancreas. We have not demonstrated altered insulin secretion with exposure of fetal human pancreas to $0.25-1.0 \mathrm{~g}$ glucose $/ 1$ and nor have we seen any difference in the response of individual pancreases between 12 and 22 weeks gestation to each of the secretagogues studied (unpublished data).

Deficiencies in glycolysis, such as impaired phosphorylation of glucose, have been implicated as a cause of 'glucose blindness' by studies in the neonatal rat [21]. Supporting a defective step in glycolysis is the report of diminshed responsiveness to $16.7 \mathrm{mmol} / 1$ glucose of newborn rat islets but enhanced insulin secretion in the presence of $10 \mathrm{mmol} / 1$ glyceraldehyde [22]. Others have suggested a more generalized defect in recognition of secretagogues, with absent insulin responses by the neonatal rat pancreas to glucose, leucine and D-glyceraldehyde [23]. In the present study, the inability of D-glyceraldehyde to stimulate insulin secretion by fetal human pancreas that responded to other secretagogues provides evidence against a major block in the glycolytic pathway above the triose phosphate step.

The effect of dibutyryl cyclic AMP was studied because it has previously been suggested that lack of glucose-stimulated insulin release by fetal islets may relate to inadequate accumulation of cyclic AMP [24]. The results of the present study confirmed that, in the presence of dibutyryl cyclic AMP, insulin secretion from the fetal human pancreas is markedly stimulated. However, in contrast to the findings in adult tissue [25], the effect of dibutyryl cyclic AMP was not dependent upon the extracellular glucose concentration. It is, therefore, unlikely that impaired glucose-stimulated insulin release results from insufficient intracellular cyclic AMP.

The present studies of the responses of fetal $B$ cells to amino acids confirm two previous reports of the response of the fetal human pancreas to stimulation by arginine or leucine $[19,26]$. The highly significant increase in basal insulin secretion from fetal human pancreas which was grown in medium with high amino acids compared with standard medium is evidence of an important role of amino acids as substrates for $B$ cell metabolism and development [27].

There was no stimulation of insulin secretion by glucose after incubation for 7 days with high amino acid concentrations. Similarly, previous exposure to $4 \mathrm{~g}$ glucose $/ 1$ did not affect acute insulin release by glucose. However it is possible (Fig. 3) that there was an effect of previous glucose incubation on the insulin release induced by theophylline.

The mechanisms which govern the development of full secretory maturation of the fetal $B$ cell are obscure, although the present data suggest that a single defect in the early steps of glycolysis, or deficiency of cyclic AMP, is unlikely. It remains to be determined whether cultured fetal human pancreas can develop the capacity to respond to a wider variety of stimuli in vivo. Despite failure to respond to some secretagogues, the use of fetal pancreas remains an important potential source of 
islets for transplantation to overcome the problems of limited availability of, and poor islet yield from, adult tissue [15].

Acknowledgements. This work was supported by the National Health and Medical Research Council of Australia and by grants from J.B.Were \& Sons, John Claude Kellion Foundation, the Gavemer Foundation, and The Perpetual Trustees and Executors Association of Australia.

\section{References}

1. Sutherland DER (1981) Pancreas and islet transplantation. II. Clinical trials. Diabetologia 20: $435-450$

2. Hegre OD, Leonard RJ, Rusin JD, Lazarow A (1976) Transplantation of the fetal rat pancreas: quantitative morphological analysis of islet tissue growth. Anat Rec 185: 209-221

3. Murrell LR (1966) Mammalian pancreatic islet tissue in organ culture. I. Methods of culture and in vitro histogenesis. Exp Cell Res 41: 350-364

4. Kedinger M, Haffen K, Grenier J, Eloy R (1977) In vitro culture reduces immunogenicity of pancreatic endocrine islets. Nature 270: 736-738

5. Lacy PE, Davie JM, Finke EH (1979) Prolongation of islet allograft survival following in vitro culture $\left(24^{\circ} \mathrm{C}\right)$ and a single injection of ALS. Science 204: 312-313

6. Bowen KM, Andrus L, Lafferty KJ (1979) Survival of pancreatic islet allografts. Lancet II: $585-586$

7. Mandel TE, Kennedy MM (1978) Differentiation of murine thymocytes in vivo and in vitro. Immunology $35: 317-331$

8. Mandel TE, Higginbotham L (1980) Organ culture and transplantation of fetal mouse pancreatic islets. Transplant Proc 11: 1505-1506

9. Mandel TE, Collier S, Carter W, Higginbotham L, Martin FIR (1980) Effect of in vitro glucose concentration on fetal mouse pancreas cultures used as grafts in syngeneic diabetic mice. Transplantation 30: 231-233

10. Mandel TE, Hoffman (Higginbotham) L, Collier S, Carter WM, DeMoore G, Martin FIR, Campbell D (1981) Organ cultured fetal pancreas: a source of islets for transplantation in diabetic mice. Transplant Proc 13: 832-836

11. Mandel TE, Hoffman L, Carter WM (1981) Long-term isografts of cultured fetal mouse pancreatic islets. The oncogenic effects of streptozotocin and the prevention of diabetic renal complications. Am J Pathol 104: 227-236

12. Lundgren G, Andersson A, Borg H, Buschard K, Groth CG, Gunnarsson R, Hellerström C, Petersson B, Ostman J (1977) Structural and functional integrity of isolated human islets of Langerhans maintained in tissue culture for 1-3 weeks. Transplant Proc 9: $237-240$

13. Herbert V, Lau KS, Gottlieb CW, Bleicher SJ (1965) Coated charcoal immunoassay of insulin. J Clin Endocrinol 25: 1375-1384

14. Collier S, Mandel TE, Hoffman L, Caruso G (1981) Organ culture of fetal mouse pancreas. The effect of culture conditions on insulin and glucagon secretion. Diabetes $30: 804-812$
15. Sutherland DER, Matas AJ, Steffes MW, Najarian JS (1976) Infant human pancreas. A potential source of islet tissue for transplantation. Diabetes 25: 1123-1128

16. Thorell JI (1970) Plasma insulin levels in normal human foetuses. Acta Endocrinol 63: 134-140

17. Milner RDG, Leach FN, Jack PMB (1975) Reactivity of the fetal islet. In: Sutherland HW, Stowers JM (eds) Carbohydrate metabolism in pregnancy and the newborn, Churchill-Livingston, Edinburgh, pp 83-104

18. Milner RDG, Cser A, Fennell JS (1977) Effect of glucose on tissue culture of human fetal endocrine pancreas. In: von Wasielewski E, Chick WL (eds) Pancreatic beta cell culture. Excerpta Medica, Amsterdam, pp 143-147

19. Maitland JE, Parry DG, Turtle JR (1980) Perifusion and culture of human fetal pancreas. Diabetes 29: 57-63

20. Ågren A, Andersson A, Björken C, Groth CG, Gunnarson R, Hellerström C, Lindmark $G$, Lunndqvist $G$, Petersson B, Swenne I (1980) Human fetal pancreas: culture and function in vitro. Diabetes 29: 64-69

21. Andersson A, Grill V, Asplund K, Berne C, Ågren A, Hellerström C (1975) Functional maturation of the pancreatic B-cell. In: Camerini-Davalos R, Cole HE (eds) Early diabetes in early life. Academic Press, New York, pp 49-56

22. Ågren A, Andersson A, Hellerström C (1976) Effects of D-glyceraldehyde and $D$-glucose on the insulin release of pancreatic islets isolated from the newborn rat. FEBS Lett 71: 185-188

23. Grill V, Lake W, Freinkel N (1981) Generalized diminution in the response to nutrients as insulin-releasing agents during the early neonatal period in the rat. Diabetes $30: 56-63$

24. Lambert AE, Jeanrenaud B, Junod A, Renold AE (1969) Organ culture of fetal rat pancreas. II. Insulin release induced by amino and organic acids, by hormonal peptides, by cationic alterations of the medium and by other agents. Biochim Biophys Acta 184: $540-553$

25. Brisson GR, Malaisse-Lagae F, Malaisse WJ (1972) The stimulussecretion coupling of glucose-induced insulin release. VII. A proposed site of action for adenosine $3^{\prime}, 5^{\prime}$-cyclic monophosphate. $J$ Clin Invest 51: 232-241

26. Milner RDG, Ashworth MA, Barson AJ (1972) Insulin release from human foetal pancreas in response to glucose, leucine and arginine. J Endocrinol 52: 497-505

27. Milner RDG, De Gasparo M, Milner GR, Wirdman PK (1979) Amino acids and development of the beta cell. In: Sutherland HW, Stowers JM (eds) Carbohydrate metabolism in pregnancy and the newborn. Springer, Berlin Heidelberg New York, pp 132-151

Received: 21 December 1981

and in revised form: 26 June 1982

Dr. Linda Hoffman

Department of Diabetes and Endocrinology

Post Office

Royal Melbourne Hospital

Victoria 3050

Australia 